\title{
Vegetation History of Laysan Island, Northwestern Hawaiian Islands ${ }^{1}$
}

\author{
7. S. Athens, ${ }^{2}$ 7. V. Ward, ${ }^{3}$ and D. W. Blinn ${ }^{4}$
}

\begin{abstract}
Paleoenvironmental investigations were undertaken on Laysan Island in the remote Northwestern Hawaiian Islands to investigate its flora before historical observations. Substantial impacts occurred to the island as a result of late nineteenth- and early twentieth-century guano mining, commercial feather collecting, and denudation of vegetation by feral rabbits. An account of Laysan's historically known vegetation is presented, followed by discussion of results from the investigation of a 16.41-m sediment core from Laysan's central hypersaline lake. The 7,000-year pollen and seed record, besides indicating the former importance of Pritchardia palms on Laysan, showed the former presence of seven previously unknown taxa, only four of which could be identified. Diatom analysis indicated fresh to brackish lake water during the early Holocene, a finding supported by the mollusk assemblage. Diatom diversity gradually decreased over time until there is a near monoculture, with types indicating a gradual increase of salinity. Hypersaline conditions were first recognizable near the top of the sequence with the appearance of Artemia zooplankton. Generally wetter conditions seem to have characterized the island before about 5,150 yr B.P., with drier conditions thereafter. The pollen record also suggests two possibly very brief periods of much drier conditions, conceivably related to El NiñoSouthern Oscillation episodes.
\end{abstract}

A paleoenvironmental study, using a wetland/lake sediment coring methodology (e.g., Binford and Leyden 1987, Flenley et al. 1991, Colinvaux et al. 1998, Athens et al. 2002, Athens and Ward 2004), was conducted on Laysan Island in the far Northwestern Hawaiian Islands (NWHI) to investigate vegetation and other environmental attributes before human activities on the island (Figure 1). Particularly as a result of guano-mining operations starting in the early 1890s, and the subsequent introduction of rabbits in about 1903, many of the native plant taxa dis-

\footnotetext{
${ }^{1}$ Manuscript accepted 2 March 2006.

${ }^{2}$ International Archaeological Research Institute, Inc., 2081 Young Street, Honolulu, Hawai'i 96826-2231 (e-mail: JSAthens@iarii.org).

${ }^{3}$ The Petroleum Institute, P.O. Box 2533, Abu Dhabi, United Arab Emirates.

${ }^{4}$ Department of Biological Sciences, Northern Arizona University, P.O. Box 5640, Flagstaff, Arizona 86011-5640.
}

Pacific Science (2007), vol. 61, no. 1:17-37

(C) 2007 by University of Hawai'i Press

All rights reserved appeared during the first two decades of the twentieth century (for the island's history see Ely and Clapp 1973, Rauzon 2001, Athens et al. 2004). In 1923, the Tanager Expedition (Christophersen and Caum 1931) documented only four native plant species remaining on the almost completely denuded island (Portulaca lutea, Santalum ellipticum, Sesuvium portulacastrum, and Tribulus cistoides). Morin and Conant (1998:1) cautioned that the Laysan ecosystem may have been altered even before the start of guano mining because "there were numerous ship landings and at least one shipwreck dating before 1859."

Because of the rapid disappearance of lowland forests that occurred with Polynesian settlement of the main Hawaiian Islands (Athens 1997, Athens et al. 2002), it is reasonable to regard the same kind of disappearance as a possibility for Laysan if there was prehistoric contact or settlement. The apparent absence of traditional archaeological sites on Laysan suggests that there was no significant prehistoric occupation (though formal survey has not been undertaken), but prehistoric Hawaiians may have been aware of Laysan's existence. They are known to have made reg- 


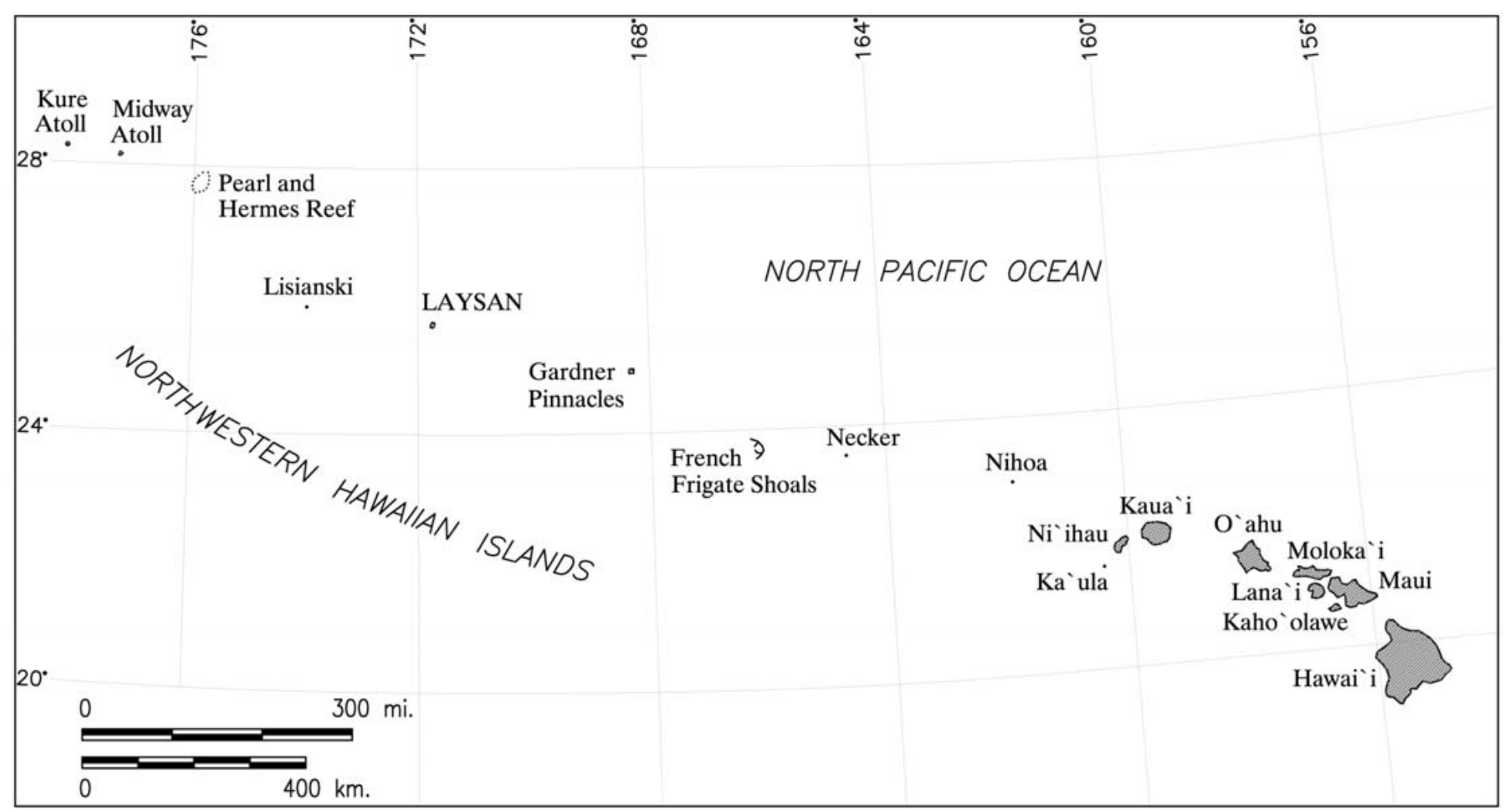

FIgURE 1. The Hawaiian archipelago, showing location of Laysan Island. 
ular visits to Nihoa and Necker Islands in the NWHI (see Cleghorn 1988, Rauzon 2001), clearly settling on the former. By extension, it is not unreasonable to suppose that their explorations may have extended to Laysan and even farther west. Thus, if prehistoric Hawaiian visits to Laysan did occur, even if sporadic and brief, these could have led to substantial vegetation changes. Paleoenvironmental coring potentially can evaluate the possibility of such earlier environmental impacts, both prehistoric and predating historic early and midnineteenth-century visits by whalers and others.

The central hypersaline lake of Laysan, the surface of which is only slightly above sea level (Bryan 1978), offers an ideal opportunity for paleoenvironmental coring (Figure 2). There is no historical evidence to indicate that the lake has ever dried out, although its surface level fluctuates slightly due to precipitation. The likely percolation of seawater into the lake presumably prevents substantial drying (that some, probably limited, percolation occurs is suggested by the coring results-see Chronology in Results and Discussion). Sediments, therefore, should have accumulated in the lake for all but the earliest part of the Holocene when sea level was too low for water to percolate into the basin to allow the deposition and accumulation of sediments. Because of the anaerobic depositional environment of most lake deposits, it was further expected that pollen preservation would be good. Although the limitations of pollen analysis are well known, the grains are nevertheless often identifiable to genus, and some types are even identifiable to species.

\section{Geography and Environment}

Laysan is located at $25^{\circ} 42^{\prime} 41^{\prime \prime} \mathrm{N}$ latitude and $171^{\circ} 44^{\prime} 06^{\prime \prime} \mathrm{W}$ longitude, approximately $1,261 \mathrm{~km}$ from Honolulu in the westnorthwest-trending NWHI chain (Figure 1). It is an isolated tiny speck of dry land with the nearest neighboring islands being Lisianski, about $185 \mathrm{~km}$ to the west, and the Gardner Pinnacles, about $325 \mathrm{~km}$ to the eastsoutheast (Bryan 1978).

The island was occupied on a long-term basis only between 1890 and 1910 for guano mining, though by 1904 the guano deposits had become nearly depleted, and the work (and possibly occupation) of the island then presumably became intermittent. A period of illegal commercial feather collecting occurred in 1909-1910, and there was a $51 / 2$-month failed resettlement attempt in 1915 (Ely and Clapp 1973, Rauzon 2001). Except for brief visits by passing ships, some with scientists, Laysan was uninhabited both before and after the guano mining/feather-collecting period. Laysan became a part of the Hawaiian Islands Bird Reservation in 1909, which in 1940 was renamed the Hawaiian Islands National Wildlife Refuge (Rauzon 2001). In recent years, the U.S. Fish and Wildlife Service and the National Marine Fisheries Service have operated small research and management camps on Laysan. Public access is not allowed.

Laysan is roughly rectangular, measuring about 2.7 by $1.7 \mathrm{~km}$ (1.77 by 1.06 miles) (Figure 2). The total land area is about $3.7 \mathrm{~km}^{2}$ (1.43 square miles). The island is entirely calcareous in nature, consisting primarily of reef sand on top of a coral platform. The coral platform is perched upon a volcanic core at unknown depth. Geologic uplift, as indicated by tilted beds of coral along the shoreline in several locations, has raised the island well above sea level to a maximum elevation of about $12 \mathrm{~m}$. A fringing reef, most extensively developed on the northwestern side, surrounds Laysan.

Laysan's climate is subtropical, like that of the main Hawaiian Islands (Ziegler 2002). Data (unpublished) collected by the Fish and Wildlife Service between 1992 and 2004 show that average annual rainfall is about $860 \mathrm{~mm}$, though both seasonal and year-toyear variation is substantial (Figures 3 and 4). As in the main Hawaiian Islands, rainfall is most abundant during winter and reduced during summer (especially the month of June). Yearly annual rainfall totals for the period of observation varied from $378 \mathrm{~mm}$ (1993) to $1,578 \mathrm{~mm}$ (2001). Minimum and maximum daily temperatures and seasonal variations closely mirror those of other Hawai' $i$ maritime locations.

Laysan was at one time thought to be an 


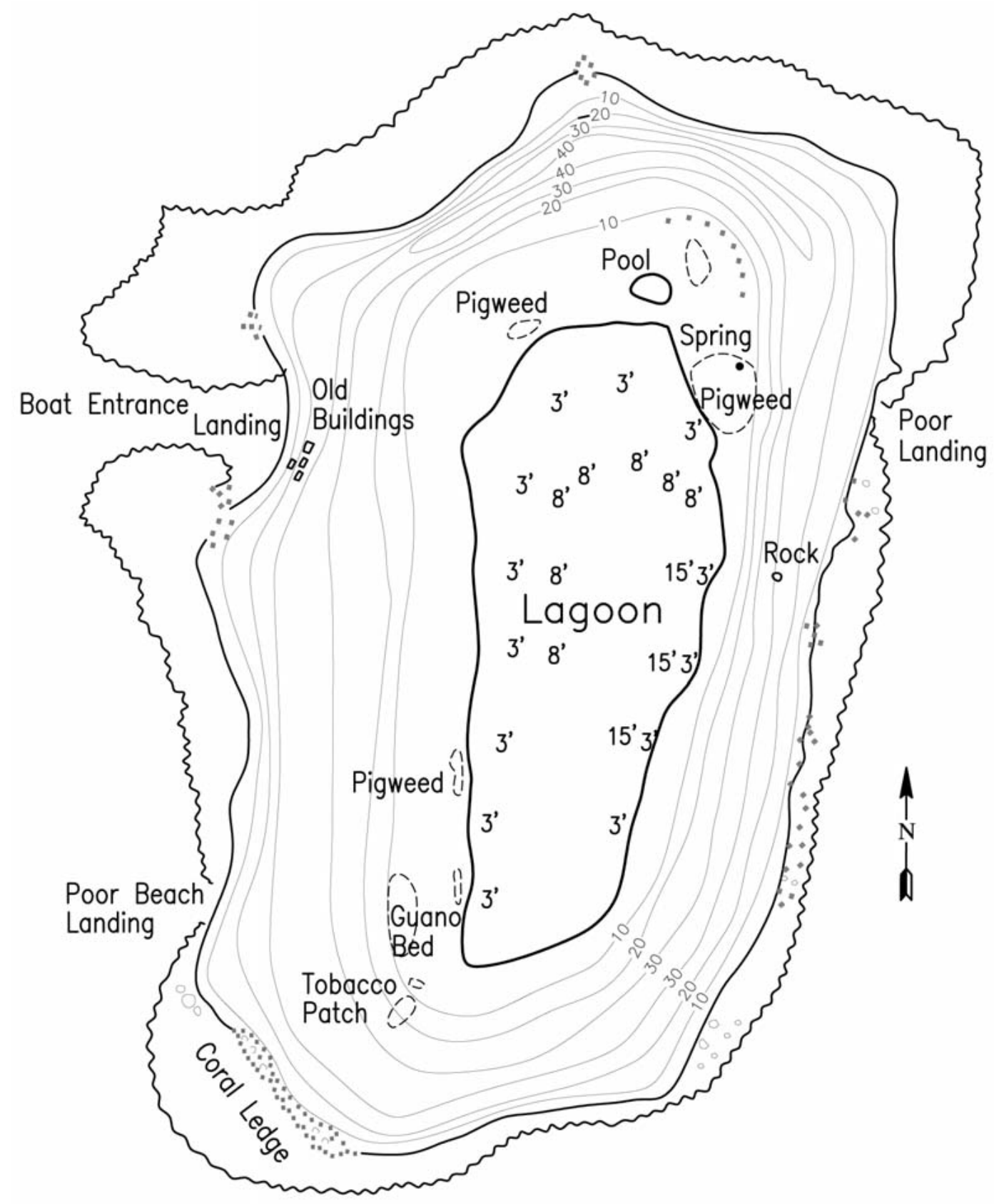

1 land mile

\section{1 sea mile}

FIGURE 2. Laysan Island, Tanager Expedition map of 1923, redrafted. One land mile equals $1.6 \mathrm{~km}$; contours and depth soundings are in feet. 


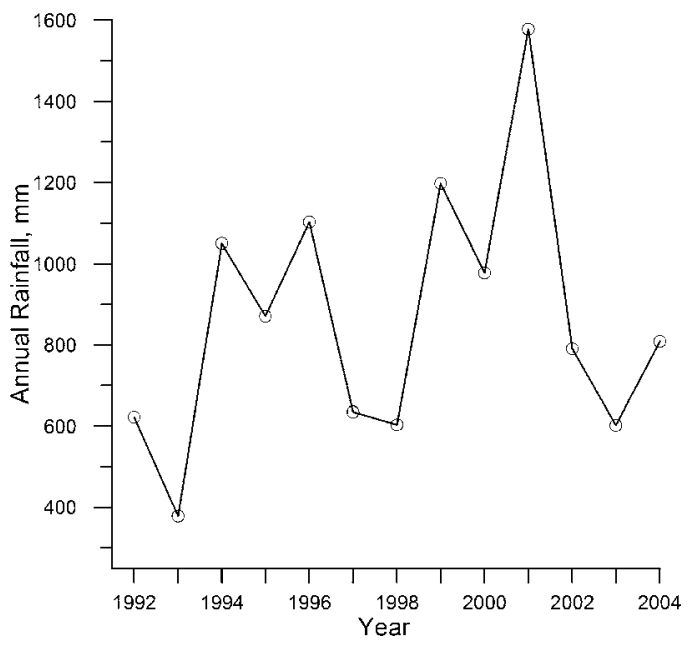

Figure 3. Annual rainfall on Laysan between 1992 and 2004. Data provided by U.S. Fish and Wildlife Service.

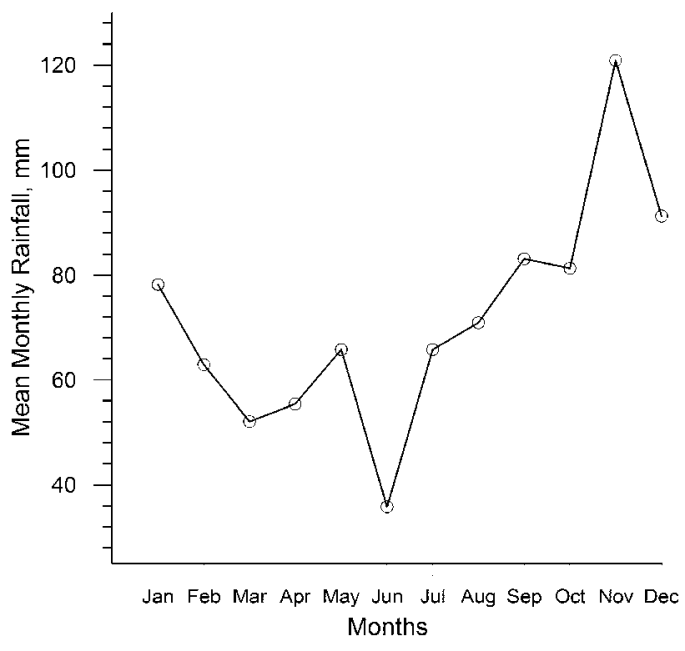

FIGURE 4. Mean monthly rainfall on Laysan between 1992 and 2004. Data provided by U.S. Fish and Wildlife Service.

atoll surrounding a now mostly filled small lagoon (see Warner 1963). With no known outlet to the ocean, it is unlikely that the current lake once could have been a lagoon, as confirmed by the coring work reported here. Rather, the central depression probably is due to the dissolution of the interior of a oncesolid coral substrate (see the bathymetry discussion later in this section).

The maximum expanse of the lake basin (bare ground to the vegetation line) is about 88 ha, though the surface water area comprised only about 65 ha in January 1966 (Maciolek 1982). A somewhat different configuration for the lake was shown by Lenz (1984). Her map (Figure 5) was based on an undated but presumably roughly contemporaneous aerial photograph. The general accuracy of her map was confirmed by observations during the coring operation in May 2003 (reported here), though some earlier aerial photographs show a slightly different configuration for the lake (see Ely and Clapp 1973). The "dry lake bed" noted on the lake's northwest side (Figure 5) is a result of the expansion and contraction of water that occasionally extends over broad flats. This is due to either seasonal rainfall and occasional storms (Ely and Clapp 1973) or perhaps high winter storm surf overtopping the east side of the island and filling the basin (Warner 1963).

Lenz's (1984) bathymetric map was prepared from 143 soundings along 16 transects. Although the lake is mostly less than a meter in depth, there are two distinct and roughly rectangular basins along its eastern side (plus a very shallow circular depression at the lake's north end). The northern of the two large basins measures about 300 by $480 \mathrm{~m}$, and the southern measures roughly 185 by $500 \mathrm{~m}$. The northern large basin has a maximum depth of $6.5 \mathrm{~m}$, and the maximum depth of the southern is $5.6 \mathrm{~m}$ (Lenz 1984). Both basins display rather steeply sloping bathymetric profiles along their sides, suggesting that they may be solution features. Lack of tidal fluctuation in the lake indicates minimal subsurface exchange of water with the ocean (Ely and Clapp 1973).

Salinity levels are similar around the lake (i.e., it is well mixed horizontally [Lenz 1984]). As reported by Ely and Clapp (1973:19), "Salinities of 12 to $15 \%$ were found by Schauinsland (1899:20), in 1896 and by Elschner (1915:33) in 1914. Warner (1963:6) reported similar concentrations ranging from $12 \%$ (June 1958) to $14 \%$ (July 


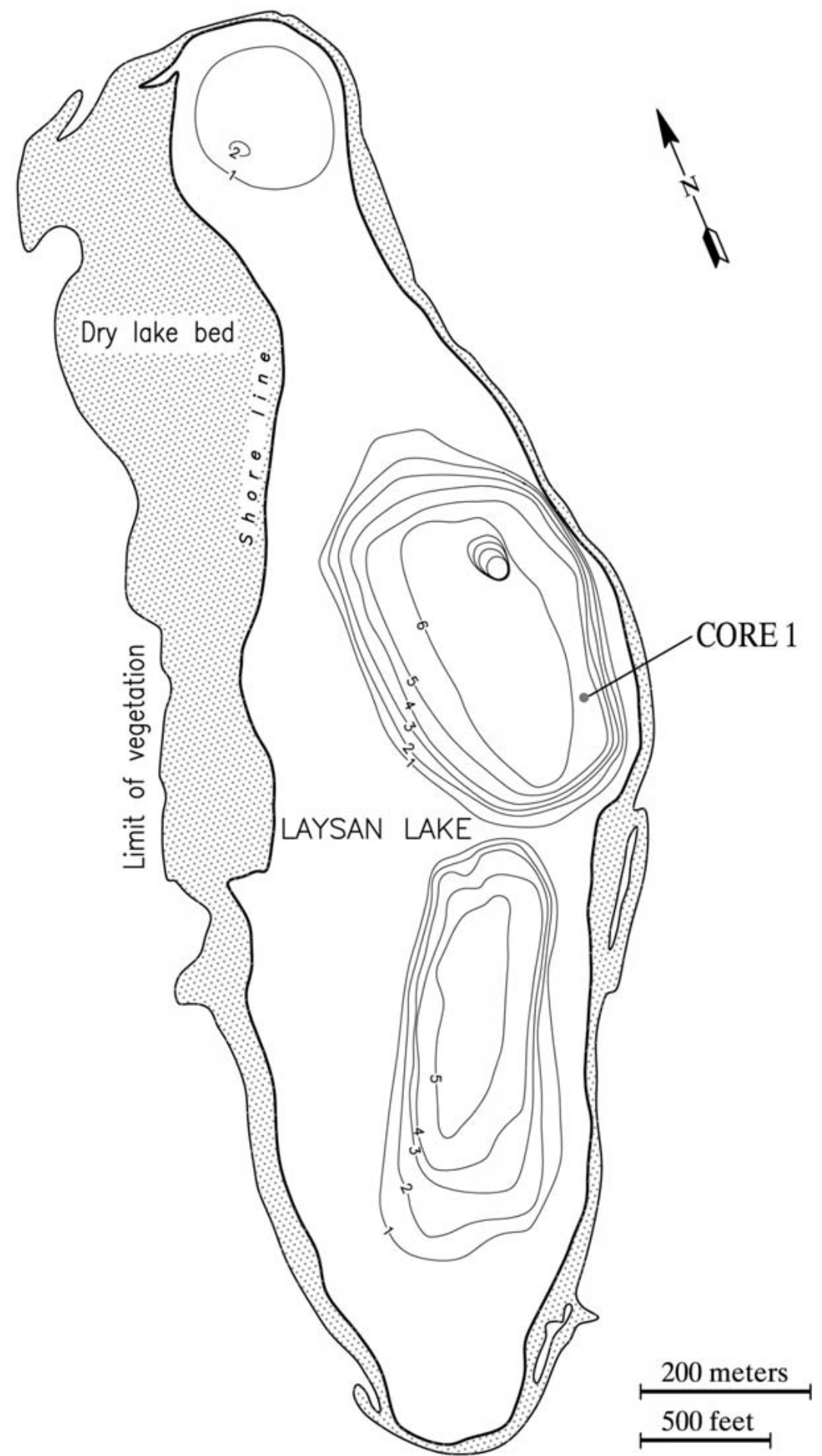

Figure 5. Bathymetric map of lake at Laysan Island, redrafted from Lenz (1984). Depth soundings are in meters. 
1959)." For comparison, the salinity of surface ocean water averages about $3.5 \%$ (or $35 \%$ ). A high level of salinity is suggested by the "greasy" feel of the lake's water and the encrustation of salt on clothing that becomes wet. Warner (1963) and Ziegler (2002) referred to the lake as "hypersaline," with water several times saltier than the ocean.

The aquatic fauna of the lake is limited to salt-tolerant invertebrates, including brine shrimp (Artemia spp.) and brine flies (Neoscatella sexnotata) (Maciolek 1982). Laysan Ducks feed on the latter (Warner 1963; note remarkable photograph in Rauzon 2001). No fish inhabit the lake.

According to Elschner (1915:44) "the most important and most interesting" of the algae of Laysan is Chrondrocystis schauinslandi Lemm., which has a jelly coat (one of 45 species collected by Schauinsland and described by Lemmermann [1905]). Also noted are Corlophaeriopsis halophila (Lemm.) and Lygnbyagloeophila, which occur with Chrondrocystis in the lake.

\section{Historical Account of Laysan's Vegetation}

Laysan is currently well vegetated, having substantially recovered, at least superficially, from the devastation caused by the introduction of rabbits (along with guinea pigs), which cleared the island of virtually all vegetation during the early twentieth century (Rauzon 2001). Scaevola taccada commonly occurs along the beach crest, and Eragrostis variabilis bunchgrass is the dominant cover of most of the island's interior. A small grove of Cocos nucifera palms occupies a swale at the north end of the island (see historical account of the establishment of this grove in Ely and Clapp 1973). Ipomoea pes-caprae occurs in locally dense stands near the lake, and Cyperus laevigatus is common along the shore of the lake. Another sedge, Cyperus pennatiformis, is also locally common in certain areas around the lake. Lamoureux's (1963) vegetation map shows the primary modern associations. Morin and Conant (1998:2) provided a summary of these associations, which occur in roughly concentric (but generally discontinuous) bands around the lake and mudflats:
"From the shore to the lake, the vegetation progressed through these native plant associations: 1) Nama sandwicensis beach association, 2) Scaevola shrub association, 3) Eragrostis bunchgrass association, 4) the viney Boerhavia-Ipomoea-Tribulus association, and 5) lakeside wetland Sesuvium-CyperusHeliotropium association."

Newman (1988) updated Lamoureux's associations to account for the rapid expansion of Pluchea. The new associations include a Pluchea shrubland fringing the lake in a narrow band just outside the wetland SesuviumCyperus-Heliotropium association (see Morin and Conant 1998). There is also a pioneer Portulaca-Tribulus association in the guano hardpan area and a weedy association of Portulaca-Eragrostis in the northwest quarter of the island. Morin and Conant (1998) indicated that the appearance of these latter two Portulaca associations was the result of the 1959 introduction to Laysan of the nonnative Portulaca oleracea.

The premodern (before guano mining) vegetation of Laysan was quite different from what is seen today. The most detailed and useful of the early accounts is by Schauinsland (1996 [1899]), a zoologist and museum curator from Germany, who was on an around-the-world collecting trip. In 1896 he made a three-month visit to Laysan to study its natural history. His plant identifications, totaling 27 species, are listed in Table 1. The only nonnative species documented by Schauinsland was Amaranthus viridis, which was likely introduced by guano workers in the early to mid-1890s (Lamoureux 1963). Subsequently, however, quite a number of plants were brought to the island. Those that became established and are still present, and those that did not become established, are listed in Morin and Conant (1998; see also Athens et al. 2004).

Schauinsland's observations are invaluable because they occurred just before massive impacts to the island caused by guano mining, commercial feather collecting, and almost complete devegetation by feral rabbits left to run and breed without hindrance (Rauzon 2001). Schauinsland's account, paraphrased by Morin and Conant (1998:2), records a 
TABLE 1

Indigenous and Endemic Laysan Flora Based on Schauinsland's (1996 [1899]) Observations (List from Morin and Conant [1998], with Slight Changes)

\begin{tabular}{|c|c|c|c|c|}
\hline Family & Scientific Name ${ }^{a}$ & Common Name & Origin & $\begin{array}{c}\text { Current Status on } \\
\text { Laysan }\end{array}$ \\
\hline \multirow[t]{4}{*}{ Poaceae (grass) } & $\begin{array}{l}\text { Cenchrus agrimonioides } \\
\text { var. laysanensis }\end{array}$ & Kāmanomano & Endemic $^{* *}$ & $\begin{array}{c}\text { Absent since } 1923 ; \\
\text { probably extinct } \\
\text { throughout range }\end{array}$ \\
\hline & Eragrostis variabilis & Kāwelu & Endemic* & Abundant \\
\hline & $\begin{array}{l}\text { Lepturus repens var. } \\
\text { subulatus }\end{array}$ & None & Indigenous & $\begin{array}{l}\text { Absent after } 1903 \text { but } \\
\text { seen again in } 1988 \\
\text { and } 1994\end{array}$ \\
\hline & Sporobolus virginicus & 'Aki'aki & Indigenous & $\begin{array}{l}\text { Absent after } 1903 \text { and } \\
\text { still absent in } 1988 \\
\text { (Newman 1988) }\end{array}$ \\
\hline \multirow[t]{2}{*}{ Cyperaceae (sedge) } & Cyperus laevigatus & Makaloa & Indigenous & Abundant \\
\hline & $\begin{array}{l}\text { Mariscus pennatiformes } \\
\text { subsp. bryanii }\end{array}$ & None & Endemic*** & $\begin{array}{l}\text { Endangered; extremely } \\
\text { localized }\end{array}$ \\
\hline Arecaceae (palm) & Pritchardia sp. & Loulu & Endemic $^{* * *}$ & $\begin{array}{l}\text { Laysan species extinct } \\
\text { by about } 1896\end{array}$ \\
\hline Santalaceae (sandalwood) & Santalum ellipticum & 'Iliahialo'e & Endemic* & Absent since 1923 \\
\hline Chenopodiaceae (goosefoot) & Chenopodium oabuense & 'Āweoweo & Endemic* & Very localized \\
\hline Amaranthaceae (pigweed) & Achyranthes atollensis & None & Endemic $^{* *}$ & Believed extinct \\
\hline Nyctaginaceae (four o'clock) & Boerhavia repens & Alena & Indigenous & Abundant \\
\hline Aizoaceae (carpetweed) & $\begin{array}{l}\text { Sesuvium } \\
\quad \text { portulacastrum }\end{array}$ & 'Ākulikuli & Indigenous & Abundant \\
\hline Portulacaceae (purslane) & Portulaca lutea & 'Ihi & Indigenous & Uncertain abundance \\
\hline Brassicaceae (mustard) & $\begin{array}{l}\text { Lepidium bidentatum var. } \\
\text { o-waibiense }\end{array}$ & 'Ānaunau & Indigenous & $\begin{array}{l}\text { Absent from Laysan } \\
\text { since } 1896\end{array}$ \\
\hline Capparaceae (caper) & Capparis sandwichiana & $\begin{array}{l}\text { Maiapilo, pua } \\
\text { pilo }\end{array}$ & Endemic* & $\begin{array}{l}\text { Missing from Laysan } \\
\text { from } 1969 \text { on? }\end{array}$ \\
\hline Zygophyllaceae (tribulus) & Tribulus cistoides & Nohu & Indigenous & Common \\
\hline \multirow{2}{*}{$\begin{array}{l}\text { Convolvulaceae (morning- } \\
\text { glory) }\end{array}$} & Ipomoea indica & Koali 'awa & Indigenous & Localized \\
\hline & Ipomoea pes-caprae & Pōhuehue & Indigenous & Common \\
\hline Hydrophyllaceae (water-leaf) & Nama sandwicensis & Hinahina kahakai & Endemic* & Common \\
\hline Boraginaceae (heliotrope) & $\begin{array}{l}\text { Heliotropium } \\
\text { curassavicum }\end{array}$ & Kīpūkai & Indigenous & Abundant \\
\hline Lamiaceae (mint) & Phyllostegia variabilis & None & Endemic $^{* *}$ & $\begin{array}{l}\text { Absent from Laysan } \\
\text { since 1903; probably } \\
\text { extinct throughout } \\
\text { range }\end{array}$ \\
\hline Solanaceae (nightshade) & Solanum nelsonii & ‘Ākia & Endemic* & $\begin{array}{l}\text { Absent from Laysan } \\
\text { since } 1903\end{array}$ \\
\hline \multirow[t]{3}{*}{ Cucurbitaceae (gourd) } & Sicyos maximowiczii & Puaokama & Endemic* & Common \\
\hline & Sicyos pachycarpus & Kūpala & Endemic* & Common \\
\hline & Sicyos semitonsus & None & Endemic*** $^{* *}$ & $\begin{array}{l}\text { Reportedly a hybrid } \\
\text { between } S . \\
\text { maximowiczii and } S \text {. } \\
\text { pachycarpus (Wagner } \\
\text { et al. 1990) }\end{array}$ \\
\hline Goodeniaceae (goodenia) & Scaevola sericea & Naupaka kahakai & Indigenous & Common \\
\hline Asteraceae (daisy) & Lipochaeta integrifolia & Nehe & Endemic* $^{*}$ & $\begin{array}{l}\text { Absent from Laysan } \\
\text { since } 1903\end{array}$ \\
\hline
\end{tabular}

Note: Exceptions: Although not listed in Laysan's flora until 1930 (apparently planted by the Tanager Expedition in 1923 [Lamoureux 1963]), the subspecies Fimbristylis cymosa subspp. spathacea and umbellato-capitata (mau'u or button sedge) are thought to be indigenous to the Hawaiian Archipelago and it is therefore the only introduced species indigenous to the main islands currently present on Laysan. The only nonnative plant present in the 1896 flora was Amaranthus viridis (slender amaranth), which became extirpated sometime after 1903 , almost certainly by the rabbits.

${ }^{a}$ Species currently present are indicated in boldface.

* Endemic to Hawaiian Archipelago.

** Endemic to Northwestern Hawaiian Islands.

*** Endemic to Laysan. 
densely vegetated island with "sandalwood trees, [former] native palms, caper bushes as tall as a man with large white fragrant flowers, tall grasses and sedges, and numerous flowering bushes and vines." Schauinsland (1996 [1899]:15) also noted that the bunchgrass Eragrostis was "foremost among the characteristic plants," and that at the wetter locations it grew to "man-high." Second in abundance was a native Chenopodium, which grew to $2 \mathrm{~m}$ and formed "an almost impenetrable thicket." As for palms, Schauinsland (1996 [1899]:16) reported that the last living examples had died off "a few years ago," recounting that he "found numerous stumps and pieces of root in the northern part of the island; some having a diameter of $50 \mathrm{~cm}$. I also found numerous remnants in the southern part of the island, not far from the lagoon. Thus, the original numbers of trees were certainly several hundred. According to verbal information, the palms had hugh [sic] fan-shaped leaves and florescences and fruit racemes. In all likelihood it was Pritchardia" (Schauinsland 1996 [1899]:45-46).

Evidence supporting Schauinsland's identification of the palms as Pritchardia is provided by several historic photographs, probably taken in 1891, showing two different trees with fan-shaped leaves, certainly Pritchardia (Figure 6) (a photograph of a different view of this same palm plus another palm and a stump is shown in Rauzon [2001]). These photographs also indicate the short stature of the palms, apparently not more than 2 or $2.5 \mathrm{~m}$ high.

Shortly before Schauinsland's visit, Lyons in 1890 collected 21 taxa of flowering plants during a visit, specifically noting the presence of Pritchardia: "among them should be mentioned the loulu palm, the maia pilo (caper), the Koali (convolvulus) and a stunted species of sandal-wood" (Lyons 1890:90-91). Loulu is the Hawaiian name for Pritchardia palms.

The last observation of the remains of Pritchardia palms on Laysan seems to have been by Elschner (1915:44), who in 1914 noted, "the decaying remains of a palm specia is to be seen on the island; most probably a Pritchardia gaudichaudii (or P. remota), the palm of Bird Island [Nihoa]."
The importance of Pritchardia, clearly a formerly common component of the flora, is suggested by Schauinsland's (1996 [1899]:16) observation of "several hundred" stumps: "the many remnants of their rotten stumps show, they were [formerly] very numerous."

The reason for the disappearance of Pritchardia is of great interest, and Schauinsland (1996 [1899]:16) did not neglect to offer an explanation: "It is not unlikely that castaways contributed to their demise, for at times, they were for sure present on the island. I found heaps of coal, in a few places, still showing the characteristic structure of palm wood. These could have been remnants of campfires, or else signs of fires kindled by carelessness."

Athens et al. (2002) proposed that the introduction of the Polynesian rat (Rattus exulans) by colonizing Polynesians was a precipitating factor in the loss of the native lowland forests, including the once-plentiful Pritchardia palms, on the main Hawaiian Islands. Morin and Conant (1998), however, noted that rats never have been documented on Laysan despite numerous ship visits. Thus, Schauinsland's "castaway" explanation remains plausible for the demise of Pritchardia on Laysan.

\section{MATERIALS AND METHODS}

The coring was undertaken between 17 and 24 May 2003. A coring platform of two joined inflatable boats was anchored in the northern basin of the lake following a series of depth probes to determine the deepest location (see Figure 5). The water depth at the coring location was $5.83 \mathrm{~m}$. A single core was extracted from the lake using a GeoCore, a hand-driven piston coring device $(3.6 \mathrm{~cm}$ bore diameter) designed for paleoenvironmental investigations (Colinvaux et al. 1998). The core reached a depth of $16.41 \mathrm{~m}$ below the lake bottom. Coring was discontinued when the sediments became very stiff, and in the process of using an auger to ream out the bore hole to reduce friction, the casing pipe became detached and the bore hole was lost. Unfortunately, due to the ship schedule for departing the island, there was insufficient 


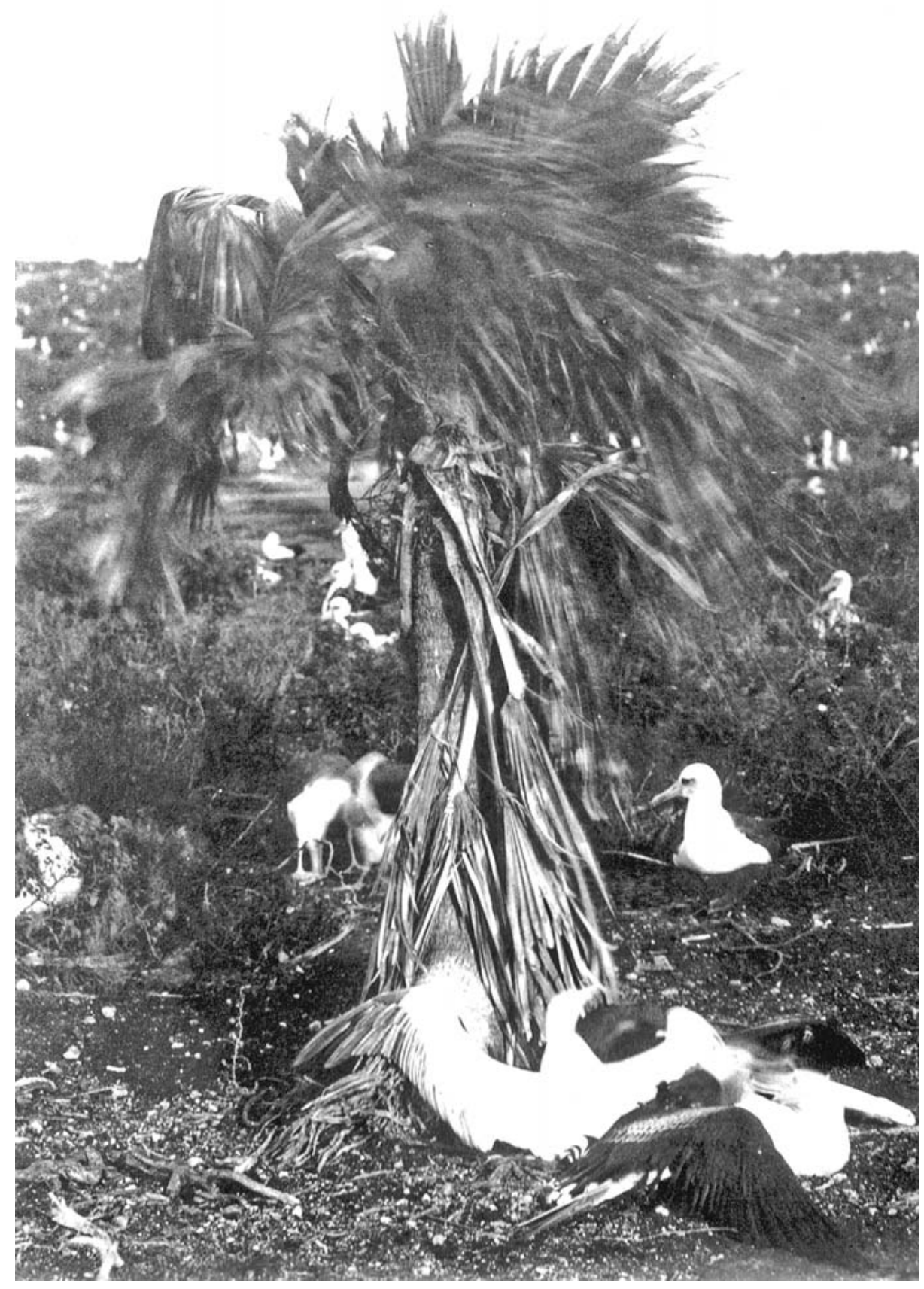

FIgURe 6. Historic photograph of Pritchardia palm on Laysan Island. Photograph reproduced with permission of the Bishop Museum (archive photo XS 37599; Book 59, p. 113). A picture of this same palm and another nearby have dates of 1891, which suggests that both photographs derive from the 1891 Rothschild Expedition (Rothschild 1893-1900). Otherwise, if the 1891 Bishop Museum date is in error, the photographs may have been taken by J. J. Williams, a Honolulu photographer, between mid-November 1892 and late January 1893. 
time to bore out another hole to attempt to retrieve possibly deeper samples.

On return to Honolulu, the aluminum core tubes, each approximately $1 \mathrm{~m}$ long, were first cut along the length of the tube on each side with a router set to the thickness of the tube. The collected sediment thereby remained undisturbed when the tube was opened for photography and analysis. Before photography, so that changes in color, texture, and contents could be clearly observed, the exposed sediment was cleaned by scraping with a constantly cleaned knife to remove any adhering film resulting from the tube having slid through the sediment during collection. After photography, the sediment in each tube was systematically described in terms of texture, color, boundaries, contents, and other properties (banding, clastics, etc.) and subsampled into mostly $1-$ or $2-\mathrm{cm}$, and up to $5-\mathrm{cm}$, intervals. The exterior surfaces of each interval sample were again carefully cleaned by scraping with a clean knife before placement in labeled plastic bags sealed with twist ties. A running list of all samples was maintained during processing. On completion of this initial processing and sediment analysis, subsamples were selected for specialized studies, including radiocarbon dating, pollen, diatoms, and malacology. There were no macrobotanical remains other than seeds of Ruppia maritima and hairlike strands of filamentous algae. Both before and after subsampling, the cores and samples were kept in refrigerated storage.

\section{RESULTS AND DISCUSSION}

\section{Sediments}

The 16.41-m-long core provided an apparently continuous sedimentary record (Figure 7). The sediment consisted almost entirely of detrital algal material; descriptions of the five main depositional units (DU) are provided in Table 2 (more detailed layer descriptions may be found in Athens et al. 2004). A relatively high concentration of hydrogen sulfide gas was present in the sediment. There was no indication of sand infilling at the top of the column, expected as a result of the destruc-

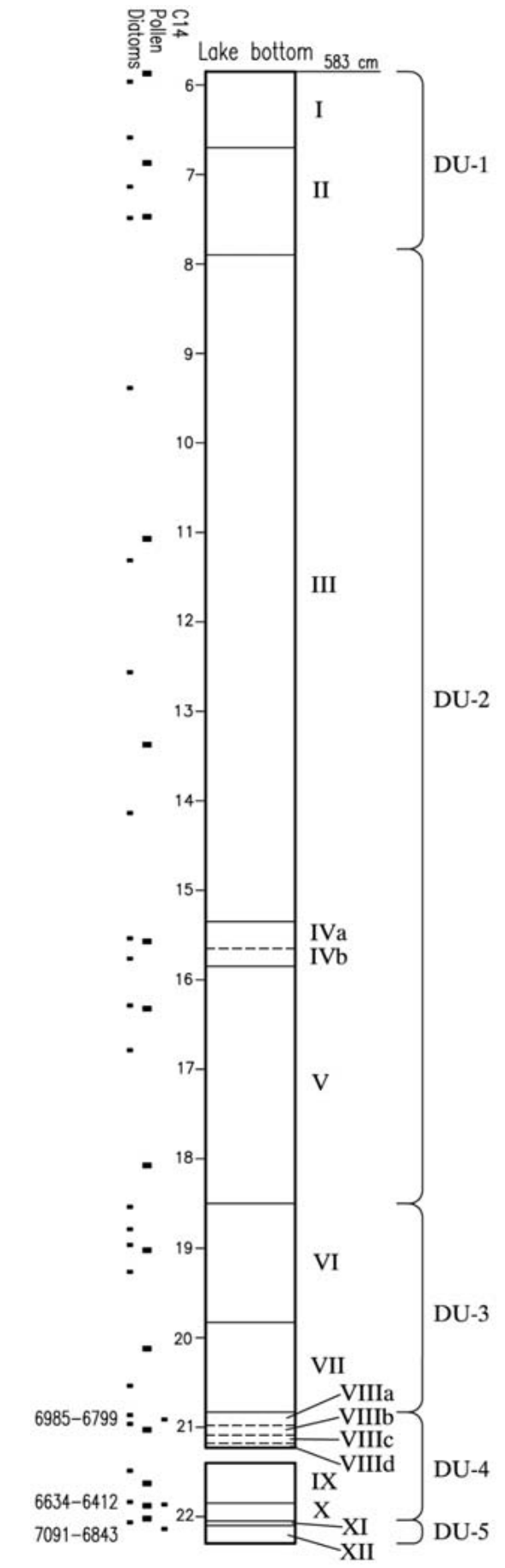

Figure 7. Profile of Laysan core. Calibrated radiocarbon date ranges (1 sigma) are indicated on the profile along with sampling intervals for pollen and diatoms. 
TABLE 2

Description of Major Depositional Units of Laysan Core

\begin{tabular}{|c|c|c|}
\hline Depositional Unit & Depth $(\mathrm{cm})$ & Description \\
\hline DU-1 & $583-783$ & $\begin{array}{l}\text { Wet gelatinous sediment formed from detrital algal material; contains } \\
\text { a very small amount of fine calcareous sand; DU-1 is distinctive as a } \\
\text { depositional unit because of its horizontal color banding; upper part } \\
\text { (Layer I) has reddish brown color, and lower part (Layer II) is } \\
\text { grayish olive green. }\end{array}$ \\
\hline DU-2 & $783-1,850$ & $\begin{array}{l}\text { Wet gelatinous sediment formed from detrital algal material; mostly } \\
\text { olive green to greenish gray, though some brownish sediment occurs } \\
\text { at } 1,536-1,587 \mathrm{~cm} \text { (Layers IVa and IVb); with the exception of } \\
\text { Layer IVa }(1,536-1,565 \mathrm{~cm}) \text {, unit has "jumbled" appearance, } \\
\text { indicating mixing; fine hairlike fibrous material } 2 \text { to } 3 \mathrm{~cm} \text { long, } \\
\text { probably algal filaments, present throughout DU-2 but more } \\
\text { common below about } 1,600 \mathrm{~cm} \text { (Layer V); at } 1,842 \mathrm{~cm} \text { (in Layer } \\
\text { V) the first lamellar concretions of cemented sand appear; these } \\
\text { concretions are similar to concretions found in areas of the current } \\
\text { dry lake bed and thus are possibly indicative of periods of } \\
\text { alternating wet and dry conditions early in the pond's formation; } \\
\text { clusters of small ( } 2 \text { to } 3 \mathrm{~mm} \text { ) gypsum nodules were present at the } \\
\text { top of Layer V. }\end{array}$ \\
\hline DU-3 & $1,850-2,083$ & $\begin{array}{l}\text { Alternating olive green and white laminations with occasional lamellar } \\
\text { concretions of cemented sand and a fair amount of fine hairlike } \\
\text { fibrous material; unlike DU-2, this unit is clearly intact; below } \\
1,985 \mathrm{~cm} \text { (Layer VII), remnant laminations, although still visible to } \\
\text { some extent, were very distorted, and the white laminations-what } \\
\text { is interpreted as aragonite--were much more common; small } \\
\text { gypsum nodules were fairly common; small air bubble voids in the } \\
\text { sediment were noted. }\end{array}$ \\
\hline DU-4 & $2,083-2,204$ & $\begin{array}{l}\text { Very stiff unit with sediment varying between lamellar and nearly solid } \\
\text { black, and also alternating thin laminations of olive green and white } \\
\text { sediment. The black and olive green sediment is gelatinous, deriving } \\
\text { from detrital algal material, and the white sediment is silty, most } \\
\text { likely aragonite; there are also thin layers and lenses of silty sand } \\
\text { and sand; there was one seed of Ruppia maritima, plus tiny marine } \\
\text { gastropods (seven taxa) and one bivalve type (Bracbidontes sp. cf. } \\
\text { crebristriatus). }\end{array}$ \\
\hline DU-5 & $2,204-2,211$ & $\begin{array}{l}\text { This unit is represented by only } 7 \mathrm{~cm} \text { of sediment due to the } \\
\text { premature termination of the coring operation; sediment consists of } \\
\text { calcareous sand (Layer XI) and silt loam (Layer XII); seeds of } \\
\text { Ruppia maritima and the same gastropods and bivalve as found in } \\
\text { DU-4 were present. }\end{array}$ \\
\hline
\end{tabular}

tion of the island's vegetation by rabbits during the early part of the twentieth century (see Ely and Clapp 1973).

The lower part of DU-2 and all of DU-3 and DU-4 contain occasional lamellar concretions of cemented sand, possibly indicating intermittent lake desiccation for the represented time periods. Similar concretions currently occur on the exposed broad flats on the northwestern side of the dry lake bed. The concretions in the core samples appar- ently formed only during the lake's early history and before the time that sea level rose substantially above the level of the accumulated lake basin sediment.

Although the 2-m-thick DU-1 appeared to be intact, with fine color banding, the sediments of the 10.67-m-thick DU-2 had a jumbled appearance. DU-2 thus seems to have been subjected to considerable movement and turbidity (though color banding of Layer IVa within DU-2 apparently represents 
TABLE 3

Radiocarbon Determinations, Laysan Paleoenvironmental Core

\begin{tabular}{|c|c|c|c|c|c|c|}
\hline Cat. No. & Lab. No. & Provenience & $\begin{array}{l}\text { Weight } \\
\text { (g)/material }\end{array}$ & ${ }^{13} \mathrm{C} /{ }^{12} \mathrm{C}(\%)$ & $\begin{array}{c}\text { Conventional } \\
\text { Age B.P. }\end{array}$ & $\begin{array}{l}\text { Calibrated } \\
\text { Age B.P.** }\end{array}$ \\
\hline $\begin{array}{l}\text { Lay, 2085.5- } \\
\quad 2086\end{array}$ & $\begin{array}{l}\text { Wk- } \\
13340^{*}\end{array}$ & $\begin{array}{l}\text { Layer VIIIb, } \\
2085.5- \\
2086 \mathrm{~cm} \mathrm{bs}\end{array}$ & $\begin{array}{l}\text { 0.86/sediment } \\
\text { (mostly algal } \\
\text { material) }\end{array}$ & $-22.0 \pm 0.2$ & $6,047 \pm 60$ & $6,985-6,797$ \\
\hline $\begin{array}{l}\text { Lay, 2085.5- } \\
\quad 2086\end{array}$ & $\begin{array}{l}\text { Wk- } \\
13340^{*}\end{array}$ & Repeat run & - & $-22.5 \pm 0.2$ & $5,945 \pm 46$ & - \\
\hline $\begin{array}{l}\text { Lay, } 2182- \\
2182.5\end{array}$ & $\begin{array}{l}\text { Wk- } \\
13341^{*}\end{array}$ & $\begin{array}{l}\text { Layer X, } \\
2182- \\
2182.5 \mathrm{~cm} \\
\text { bs }\end{array}$ & $\begin{array}{l}\text { 1.20/sediment } \\
\text { (mostly algal } \\
\text { material) }\end{array}$ & $-20.8 \pm 0.2$ & $5,721 \pm 55$ & $6,634-6,412$ \\
\hline $\begin{array}{l}\text { Lay, 2182- } \\
2182.5\end{array}$ & $\begin{array}{l}\text { Wk- } \\
13341^{*}\end{array}$ & Repeat run & - & $-20.7 \pm 0.2$ & $5,833 \pm 46$ & - \\
\hline $\begin{array}{l}\text { Lay, 2208- } \\
2209.5\end{array}$ & $\begin{array}{l}\text { Wk- } \\
13342^{*}\end{array}$ & $\begin{array}{l}\text { Layer XI, } \\
2208- \\
2209.5 \mathrm{~cm} \\
\text { bs }\end{array}$ & $\begin{array}{l}\text { 0.15/shell } \\
\text { (Brachidontes } \\
\text { sp. cf. } \\
\text { crebristriatus) }\end{array}$ & $0.5 \pm 0.2$ & $7,178 \pm 57$ & $7,091-6,843$ \\
\hline
\end{tabular}

* AMS procedure used to date all samples; repeat runs are randomly undertaken at the initiative of the laboratory to evaluate consistency of results. bs, below surface.

** Calibration from Calib 3.0.3 computer program (Stuiver and Reimer 1993); all dates have a 1 sigma age range. Calibration based on decadal treering dataset to 6,000 cal. B.C. (ca. 7,200 ${ }^{14} \mathrm{C}$ yr B.P.). Sample Lay, 2208-2209.5 was calibrated using marine model with Delta-R value of $690 \pm 90$, from Dye (1994).

a brief interlude of stability when sediments accumulated in a normal horizontal layering manner). The location of the core near the steep edge of the east side of the basin (Figure 5) suggests that the turbid appearance of DU-2 could be the result of gravitational slumping from the steep eastern side. Another factor possibly contributing to slumping might have been the spontaneous and possibly explosive discharge of hydrogen sulfide gas through the sediment once pressure thresholds were reached in sediment that had been initially deposited on the basin sidewalls. Although speculative, this latter factor possibly could account for the "granular" appearance of the sediment better than slumping alone.

The alternating algal and aragonite laminations, especially as seen in DU-4, may reflect periods of algal growth and its absence, possibly due to periodicity in the influx of freshwater to the lake (from rainfall) and subsequent evaporative cycles that created saline or hypersaline conditions with eutrophication or hypereutrophication. In this respect, Warner (1963) noted the occasional forma- tion of a freshwater lens on the lake surface due to seasonal rains and groundwater seeps. The presence of small gypsum nodules in DU-3 is consistent with an origin from evaporative processes (i.e., formation from an aqueous solution as a result of concentration and precipitation through extensive or total evaporation-see Sherman [1999]). A similar sedimentary sequence was documented at the Ordy Pond sinkhole on O'ahu (Athens et al. 1999, 2002).

\section{Chronology}

The core's chronology is based on three radiocarbon determinations using the accelerator mass spectrometry (AMS) procedure. All samples are from the deepest part of the core. The distribution of these samples with respect to the sediment layers is shown in the core profile (Figure 7). Sample details and dating results are presented in Table 3 . An interpretation of the dating sequence is provided in a depth-age graph using calibrated radiocarbon ages and assuming a constant rate of deposition (Figure 8). 


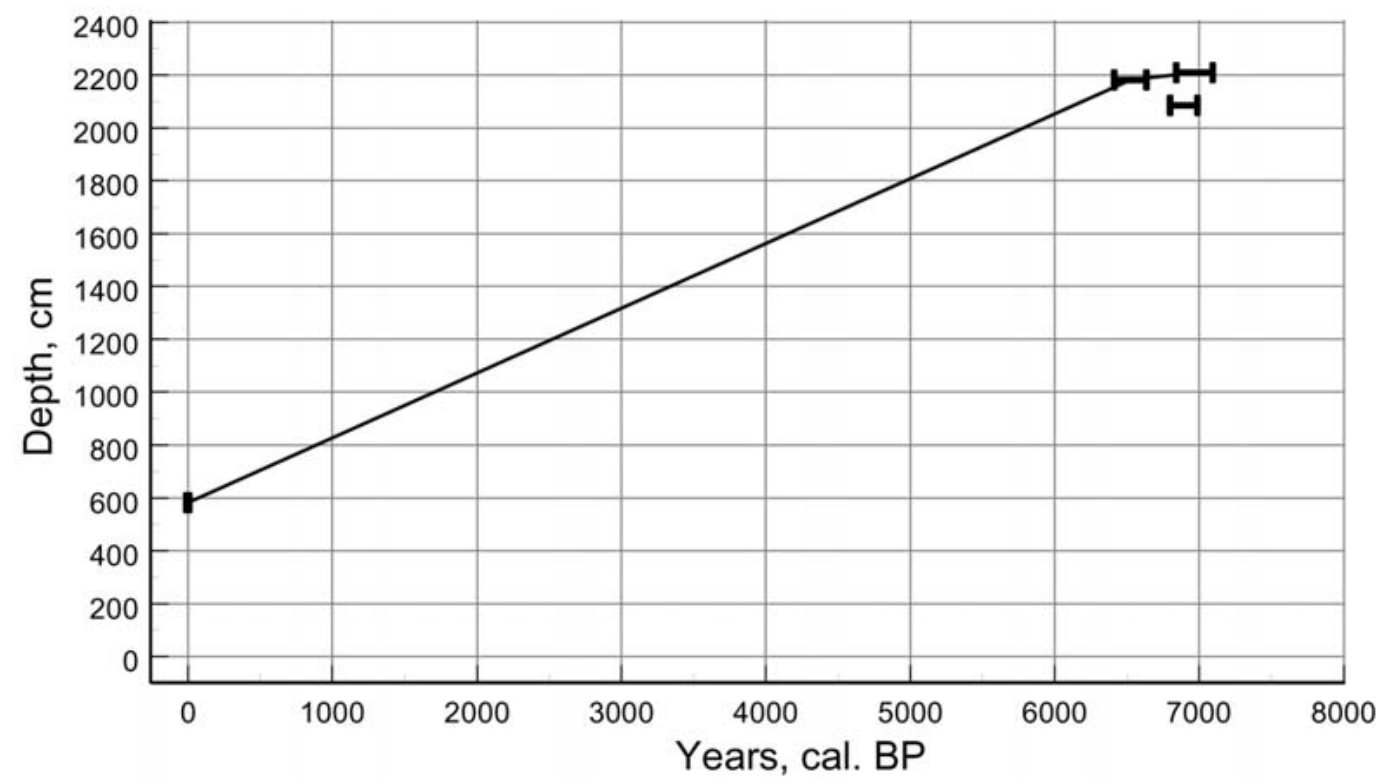

FIGURE 8. Depth-age plot of calibrated radiocarbon determinations from Laysan core using a linear interpolation model connecting the midpoint of each date range (1 sigma) with the surface (lake bottom) age set at zero and 583 $\mathrm{cm}$ below the lake surface.

As indicated by the deepest sample, the base of the core dates to about 7,000 yr cal. B.P. (calibrated conventional age before present, with "present" set at A.D. 1950). The other two samples, from slightly above, essentially confirm this result, having mean calibrated ages of about 6,900 and 6,500 years. The apparent chronological inversion of the date at $2,085.5 \mathrm{~cm}$ may be related to the metabolism of old carbon in solution by algae that formed the sediment used for dating, making its radiocarbon age older than it should be. This is a common problem when dating detrital algal sediments from calcareous environments (see Athens and Ward 1997, Athens et al. 1999). As a check on the results of the two sediment samples, a bivalve shell was also dated from the deepest location for which such shell was available $(2,209.5$ $\mathrm{cm})$. The 7,000-yr age of this sample supports the general accuracy of the other two samples, though it also suggests that the $2,085.5 \mathrm{~cm}$ sample may be slightly too old.

The jumbled sediment indicates disturbance in most of DU-2, making the utility of the depth-age curve for dating specific points between 783 and $1,850 \mathrm{~cm}$ uncertain. Pollen analysis (discussed in a later section), nevertheless, suggests that DU-2 certainly dates to a time before historic human impacts regardless of any possible problems with its stratigraphic integrity.

Seven thousand years ago global sea level was roughly 16 to $17 \mathrm{~m}$ below its modern level (which is roughly just below the current lake level), and 8,000 yr ago it would have been approximately $22 \mathrm{~m}$ below its modern level (see Fairbanks 1989). For the periods represented by DU-4 and DU-5, sea level must have been just above the lake bottom represented by these units. Thus, at 6,000 to 7,000 cal. B.P. sea level would have been about 16 to $17 \mathrm{~m}$ below current lake surface and constantly rising, whereas lake bottom depth would have been between 20.83 and $22.11 \mathrm{~m}$ below the current lake level at that time. This makes sense because Ruppia maritima seeds and at least one brackish-water gastropod (see later section) indicate that the lake basin represented by the DU-4 and 5 sedimentary units had brackish water at the time of deposition. With sea level above the 


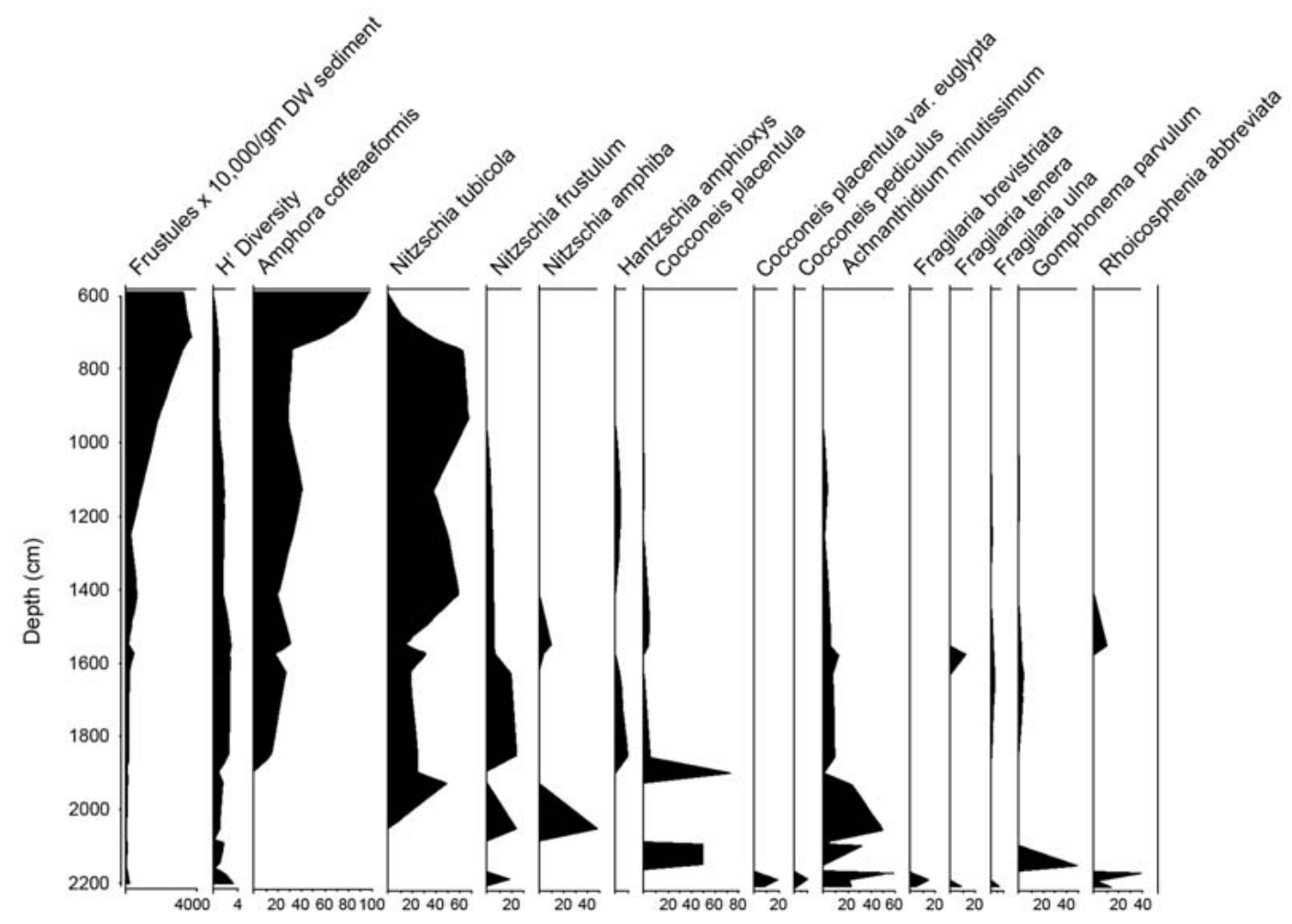

FIGURE 9. Diatom diagram showing relative abundance of selected taxa arranged by core depth.

lake basin, there must have been some minimal percolation of seawater into the lake during even the earliest part of the sedimentary sequence. By the later part of DU-3, with continued sea level rise and percolation, the water column in the lake appears to have deepened substantially as indicated by the lack of lamellar concretions of cemented sand in the sediment.

Assuming the applicability of $\mathrm{O}^{\prime}$ ahu data for Laysan, modern sea level would have been reached about 5,000 or $6,000 \mathrm{yr}$ ago (depending on the model). With little or no pause, however, sea level continued to rise, reaching about $2.0 \mathrm{~m}$ above mean sea level ca. 3,500 cal. B.P. before drawdown, with stabilization at the modern level about 2,000 cal. B.P. (Athens and Ward 1993, Fletcher and Jones 1996, Grossman and Fletcher 1998). Although the highstand presumably affected Laysan, it is not in evidence in the core rec- ord (there is no marine debris in the core record as might be expected from the greater ease for storm waves to overtop parts of the island during the highstand).

\section{Diatoms}

Analysis of 22 sample intervals for diatoms disclosed a total of 30 taxa (Figure 9 [details in Athens et al. 2004]). Most taxa in the deepest core section commonly occur in freshwater to brackish-water environments, though they have a tendency to prefer more alkaline conditions. Also, Cocconeis placentula var. euglypta, C. pediculus, and Rhoicosphenia abbreviata in these intervals suggest submerged vegetation because all are frequently found attached to filamentous green algae and/or aquatic macrophytes in shallow-water environments (Patrick and Reimer 1966). This concurs with the observation of Ruppia mari- 
tima seeds in the earlier intervals. The appearance of Amphora coffeaeformis in the 1,850 - to $1,851-\mathrm{cm}$ interval marks the beginning of highly alkaline conditions in the lake, presumably a result of rising sea level and increased percolation of saltwater into the lake basin. The 1,410- to $1,413-\mathrm{cm}$ interval marks the beginning of a continual decline in diatom diversity, and by the $588-$ to $590-\mathrm{cm}$ interval there is virtually a monoculture. Submerged aquatic macrophytes would have largely disappeared with the transition in dominance of $A$. coffeaeformis and Nitzschia tubicola.

Zooplankton filter-feeding structures, probably derived from Artemia, were present only in DU-1 (to a maximum depth of 710$713 \mathrm{~cm})$. Artemia is a hypersaline zooplankter; therefore its appearance suggests a substantial change in lake chemistry, with it either becoming hypersaline or the level of hypersalinity increasing.

\section{Mollusks}

Eight mollusk taxa were identified in Layers VIIId and XII (DU-4 and -5); seven were gastropods, and one was a bivalve (Table 4). These taxa indicate brackish rather than freshwater conditions during the early history of the lake. Freshwater in the basin presumably derived from rainwater or subsurface seeps but mixed with saltwater percolating into the basin from the rising ocean.

\section{TABLE 4}

Mollusk Identifications from Laysan Core, 2,120.5- to 2,121-cm Interval

\begin{tabular}{lc}
\hline \hline Gastropoda & Bivalvia \\
\hline Cerithium sp. cf. zebrum & Brachidontes sp. cf. \\
Ittibittium sp. cf. parcum & \\
Diala semistriata & \\
Eatoniella (Caveatoniella) & \\
janetaylorae & \\
Pygrulina oodes & \\
Turbonilla sp. cf. thaanumi & \\
Unidentified gastropod &
\end{tabular}

Note: Identifications by Regina K. Kawamoto; taxonomic references in Athens et al. (2004).

\section{Pollen Analysis}

Fourteen core samples were processed for pollen analysis (see Athens et al. [2004] for processing protocols and count data). The samples yielded a low diversity assemblage, which was expected given Laysan's low topography, small size, and remote location. The preservation of pollen grains was fair to good, dependent in part on the type of pollen grain. Microscopic charcoal particles, often indicative of human presence on Pacific islands (e.g., Athens et al. 2002, Athens and Ward 2004, 2005a,b), were not observed.

The results of the pollen analysis are summarized in Figure 10. Three pollen zones were assigned to the profile based on shifts in the pollen spectra and relative abundance. Zone A spans the basal part of the profile from 2,200 to $1,850 \mathrm{~cm}$, Zone B covers the middle portion from 1,850 to $800 \mathrm{~cm}$, and Zone $\mathrm{C}$ records the upper portion from 800 to $583 \mathrm{~cm}$.

Zone C, corresponding to DU-1, may be entirely historic given the presence of a single grain of Casuarina equisetifolia in the 740- to $745-\mathrm{cm}$ interval. However, at $157 \mathrm{~cm}$ below the top of the sediment column, this grain seems to be too old to be from the earliest known Casuarina, planted in 1905, much less those planted in later years (see Ely and Clapp 1973). Although speculative, one implication of Casuarina at this depth is the possibility that it was once present on the island long before 1905, having been introduced during the early historic period. Other pollen taxa also suggest that Zone $\mathrm{C}$ is entirely historic, with the bottom interval showing higher proportions (compared with earlier Zone B intervals) of cheno-ams (Chenopodiaceae-Amaranthaceae type) and grass, and a substantial reduction in Pritchardia, implying the onset of disturbance.

Zone A, corresponding to DU-3, -4 , and -5 , dates from ca. 7,000 to 5,150 cal. B.P., and Zone B, corresponding to DU-2, dates between 5,150 cal. B.P. and the historic period, though as previously noted, the sediment of this unit may be stratigraphically compromised.

In general, the sedge "rounded type" 


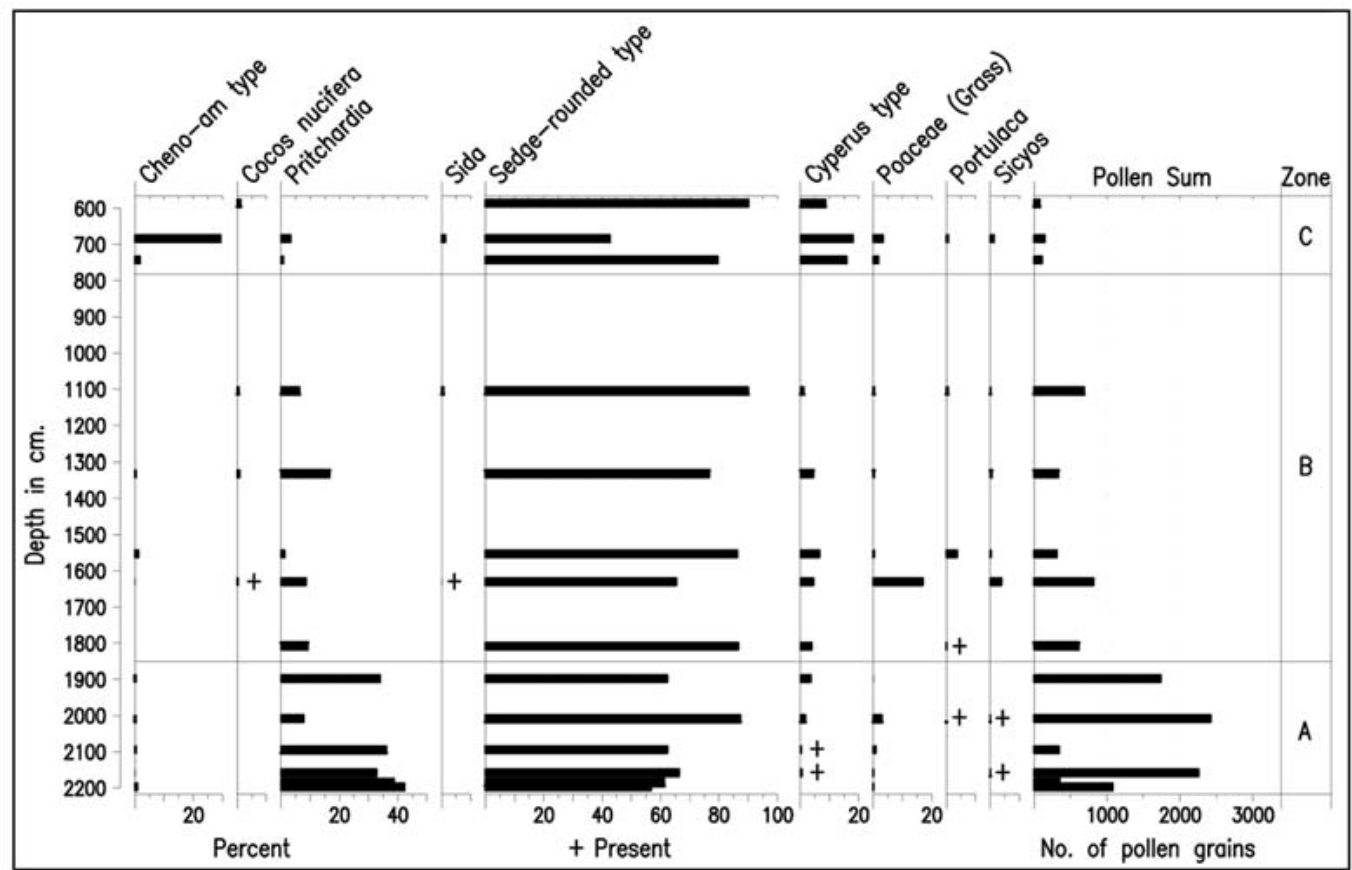

Figure 10. Pollen diagram plotted histogram style, arranged by core depth (pollen analyst: Jerome V. Ward).

dominates the pollen record throughout the core, at 60 to $85 \%$; the Cyperus type becomes important only in Zone C. Pritchardia, the cheno-am type, and Sicyos were usually well preserved; Portulaca grains were seen only as fragments; and Cocos grains in some intervals were poorly preserved. Pteridophyte spores were absent, which was unexpected because certain pteridophyte taxa are usually plentiful and well preserved in main island cores.

The middle interval of pollen Zone C matches Schauinsland's (1996 [1899]) description of Laysan's vegetation in that Chenopodium was the "commonest plant on the island" after grass. Further, in the topmost interval, Chenopodium is altogether absent, corresponding to today's landscape. There is also Cocos in this uppermost interval, certainly reflecting historically planted trees, but no Pritchardia as expected, though a few grains were present in the earlier intervals of Zone $\mathrm{C}$, evidently documenting its decline before extirpation. As already noted, the Cyperus type becomes much more important in Zone $\mathrm{C}$ compared with preceding intervals.
Pollen Zone B is mainly notable for substantially higher counts of Pritchardia compared with Zone C; roughly between 5 and $20 \%$ for the analyzed intervals. In addition Cocos is present, definitely to a depth of $1,627-1,632 \mathrm{~cm}$, and questionably noted in the 1,805 - to $1,810-\mathrm{cm}$ and $1,896-$ to $1,900-$ $\mathrm{cm}$ intervals, the latter interval being in Zone A and likely dating to ca. 5,400 cal. B.P. (Athens et al. 2004:26).

Pollen Zone A is notable for its very high Pritchardia counts, exceeding $40 \%$ in the basal interval and $30 \%$ in all but one of the other intervals. Besides the sedge "rounded type" and Cyperus type, the 2,007- to 2,010$\mathrm{cm}$ interval was particularly productive, having Boerbavia, the cheno-am type, Nama, Portulaca, Sesuvium, Sicyos, and Tribulus, in addition to a relatively high concentration of Poaceae.

The paleoenvironmental evidence includes up to seven plant taxa not identified by Schauinsland. These are Cocos nucifera, Hibiscus, Ruppia maritima (identified from seeds and not pollen), Sida, and three unknown pollen types. 
The apparent prehistoric presence of Cocos nucifera pollen in the core below the uppermost obviously recent/modern interval was a surprise. Because the securely identified premodern Cocos occurs only within DU-2, the disturbed unit, its age is uncertain. This is important for determining whether it possibly could be a prehistoric Polynesian introduction, as would be implied by a relatively late time of introduction, or if it arrived on Laysan by natural means, as would have to be the case if its initial occurrence was early. The latter seems more probable given the depth of the earliest securely identified Cocos grains at 1,627-1,632 cm (two grains) and additional "possible" grains at 1,805-1,810 and 1,896$1,900 \mathrm{~cm}$ (not indicated on Figure 10 diagram). A natural introduction is also in keeping with the absence of archaeological evidence for Polynesian visits to Laysan. Whatever the specific date, the pollen indicates that Cocos palms were present on Laysan long before historic coconuts were planted on the island beginning in 1902 (see Ely and Clapp 1973 [these 1902 plants evidently died before Schauinsland's arrival]). The Cocos pollen at the top of the pollen diagram likely derives from palms planted in 1959 (see Ely and Clapp 1973).

The fact that Schauinsland missed seeing Hibiscus and Sida suggests that these plants had disappeared before his visit. The absence of Ruppia maritima at the time of Schauinsland's visit can be understood as a result of the lake water changing from brackish to saline and then to hypersaline, a process beginning during the middle to early Holocene. Ruppia disappeared simply as a result of habitat loss.

The three unknown pollen types were documented primarily in Zone B, though one grain occurred in the middle of Zone $\mathrm{C}$ (Athens et al. 2004). These are interesting because they do not appear to pertain to the indigenous and endemic families documented by Schauinsland and are not otherwise noted in the pollen record (listed in the next paragraph). Thus, they appear to be new taxa for Laysan, but unfortunately their identifications are unknown.

Taxa observed by Schauinsland but not observed in the pollen study even at the family level (some pollen types cannot be identified to the genera or species level) include Santalum ellipticum, Lepidium bidentatum, Heliotropium curassavicum, Phyllostegia variabilis, Solanum nelsonii, and Scaevola taccada. Their absence in the pollen record could be related to any of several factors: (1) limited production of pollen by the plant; (2) poor dispersal of the limited pollen; (3) fragility of the pollen, affecting its survival in the pollen record; and (4) the limited occurrence of the plant, which thereby limited the amount of pollen available for deposition in sufficient quantity to be found.

\section{Other Pollen Observations}

The absence of Poaceae pollen in the topmost core sample (at the current lake bottom) seems unusual in view of the current and recent historic dominance of Eragrostis on the island. Also, grasses are usually plentiful pollen producers (grass pollen can only be identified to the family level). Because Poaceae pollen, with two exceptions, has a very limited occurrence in the other intervals (one to three grains, and two intervals without any), it appears that Eragrostis is not an abundant pollen producer. Thus, its absence in the uppermost interval may be a sampling problem, especially possible because this interval had the lowest total pollen count in the core record.

Two important exceptions to the low Poaceae counts are in intervals at 1,6271,632 and 2,007-2,010 $\mathrm{cm}$. The 1,627- to $1,632-\mathrm{cm}$ interval had 139 Poaceae pollen grains, about $17 \%$ of the total, and the $2,007-$ to 2,010-cm interval had 72 grains, about $4 \%$ (percentages without the Cyperaceae types are 56 and 26, respectively). These spikes, and especially the one represented at the 1,627 - to $1,632-\mathrm{cm}$ interval, must be indicative of major short-term vegetation changes on Laysan, perhaps corresponding to climate perturbations (see following section).

Another related point is that there is no spike in the occurrence of cheno-ams corresponding with the spike in Poaceae in the $2,007-$ to $2,010-\mathrm{cm}$ and $1,627-$ to $1,632-\mathrm{cm}$ 
intervals. Because both Poaceae and chenoams are often disturbance indicators favoring more open conditions, it was expected that changes in one would correspond with changes in the other. This was the pattern in the Ordy Pond pollen diagram on $\mathrm{O}^{\prime}$ ahu (Athens et al. 1999, 2002). The reason the two pollen types did not covary in the two intervals just mentioned for Laysan is unclear. Nevertheless, the cheno-am pollen is unusually abundant in the $681-$ to $687-\mathrm{cm}$ interval near the top of the core, perhaps a response to the substantial loss of the Pritchardia overstory during the nineteenth century.

\section{Paleoclimate}

It is unclear what climatic conditions may have been like before 7,000 cal. B.P. because the core sedimentary record only begins at that time. However, the substantial decline in the frequency of Pritchardia pollen above the 1,896- to $1,900-\mathrm{cm}$ interval in Zone B suggests possibly continuously wetter conditions in Zone A before ca. 5,150 cal. B.P. and drier conditions thereafter. The punctuated increases in Poaceae pollen in the 2,007 - to $2,010-\mathrm{cm}$ and $1,627-$ to $1,632-\mathrm{cm}$ intervals may indicate brief episodes of much drier conditions. Whether these episodes could be related to El Niño-Southern Oscillation conditions is not known. The drier conditions suggested by Zone B seem to coincide with other evidence for generally drier conditions during the mid-Holocene in $\mathrm{Ha}$ wai'i (Athens 1997).

\section{CONCLUSIONS}

Paleoenvironmental investigations on Laysan Island provide insight into vegetation and environmental conditions before the advent of human contact and impacts. The most important conclusion is that the physical environment has not remained static during the Holocene. The central lake, a dominant feature of the landscape, has changed from a fresh/brackish-water basin in the early Holocene to a saline body of water and finally, in more recent times, to a hypersaline lake. One consequence of changing salinity is the ap- pearance of Artemia zooplankton in the lake with the onset of Zone C.

As for vegetation, Pritchardia palms appear to have been a dominant component of the flora during the early Holocene and then somewhat less so until recent times when they disappeared altogether, possibly a result of human contact. Human impact may have been indirect in the form of introduced rats, as postulated for the main Hawaiian Islands (Athens et al. 2002) or the result of the cutting and burning of the trees for firewood by "castaways" and passing ships during the nineteenth century as suggested by Schauinsland 1996 [1899]. The mid-Holocene decline of Pritchardia documented in Zone B could have been the result of longer-term climatic drying, with several short-term arid episodes indicated by spikes of Poaceae counts during both the early and mid-Holocene.

Four new taxa were identified for Laysan as a result of this study, including prehistoric and possibly prehuman Cocos nucifera, Hibiscus, Sida, and Ruppia maritima. In addition, there were three other new but unidentified pollen taxa (for a total of seven new taxa). The presence of possibly prehuman Cocos is especially interesting because it suggests longdistance transport from the western Pacific at a very early time, presumably a result of the natural dispersal of nuts by ocean currents. Early Holocene (prehuman) Cocos has been documented on Palau, Guam, and Saipan (Athens and Ward 2004, 2005a,b), but Cocos almost certainly did not arrive in the main Hawaiian Islands until the advent of humans (Athens 1997, Athens et al. 2002).

\section{ACKNOWLEDGMENTS}

We thank the Pacific Islands Ecoregion, Division of Ecological Services, of the U.S. Fish and Wildlife Service for their sponsorship of the Laysan Island investigations and for all of the logistical support that was entailed in arranging for J.S.A.'s travel to, and stay on, the island. We also thank Elizabeth Flint and Stefan Kropidlowski of that agency for providing us with the rainfall data. The field assistance provided by Kevin Payne and Matthew Toomey of the U.S. Fish and Wild- 
life Service is also gratefully acknowledged. Finally, we are indebted to Regina K. Kawamoto of Bishop Museum and University of Hawai'i for identification of the mollusks.

\section{Literature Cited}

Athens, J. S. 1997. Hawaiian native lowland vegetation in prehistory. Pages 248-270 in P. V. Kirch and T. L. Hunt, eds. Historical ecology in the Pacific islands: Prehistoric environmental and landscape change. Yale University Press, New Haven, Connecticut.

Athens, J. S., H. D. Tuggle, J. V. Ward, and D. J. Welch. 2002. Avifaunal extinctions, vegetation change, and Polynesian impacts in prehistoric Hawai'i. Archaeol. Oceania 37:57-78.

Athens, J. S., and J. V. Ward. 1993. Environmental change and prehistoric Polynesian settlement in Hawai'i. Asian Perspect. 32 (2): 205-223.

1997. Liliha paleoenvironmental study, Honolulu, Hawai'i. Report prepared for Scientific Consultant Services, Inc., Honolulu. International Archaeological Research Institute, Inc., Honolulu.

- 2004. Holocene vegetation, savanna origins and human settlement of Guam. Pages 15-30 in V. Attenbrow and R. Fullagar, eds. A Pacific odyssey: Archaeology and anthropology in the western Pacific: Papers in honour of Jim Specht. Rec. Aust. Mus. Suppl. 29.

2005a. Holocene paleoenvironment of Saipan: Analysis of a core from Lake Susupe. Report prepared for Division of Historic Preservation, Department of Community and Cultural Affairs, Commonwealth of the Northern Mariana Islands, Saipan. International Archaeological Research Institute, Inc., Honolulu. 2005b. Holocene paleoenvironment and landscape change. Vol. 4. Palau Compact road archaeological investigations, Babeldaob Island, Republic of Palau, Phase I: Intensive archaeological survey. Report prepared for Department of the Army, U.S. Army Engineer District, Honolulu, Fort Shafter, Hawai'i. Interna- tional Archaeological Research Institute, Inc., Honolulu.

Athens, J. S., J. V. Ward, and D. W. Blinn. 2004. Holocene paleoenvironment of Laysan Island, Northwestern Hawaiian Islands. Report prepared for Pacific Islands Ecoregion, Division of Ecological Services, U.S. Fish and Wildlife Service, Honolulu. International Archaeological Research Institute, Inc., Honolulu.

Athens, J. S., J. V. Ward, H. D. Tuggle, and D. J. Welch. 1999. Environment, vegetation change, and early human settlement on the 'Ewa Plain: A cultural resource inventory of Naval Air Station, Barbers Point, O`ahu, Hawai'i, Part III: Paleoenvironmental investigations. Report prepared for Belt Collins Hawai'i, Honolulu, under contract to the Department of the Navy, Commander, Pacific Division, Pearl Harbor. International Archaeological Research Institute, Inc., Honolulu.

Binford, M. W., and B. Leyden. 1987. Ecosystems, paleoecology and human disturbance in subtropical and tropical America. Quat. Sci. Rev. 6:115-128.

Bryan, E. H., Jr. 1978. The Northwestern Hawaiian Islands: An annotated bibliography. U.S. Fish and Wildlife Service, Honolulu, Hawai'i.

Christophersen, E., and E. L. Caum. 1931. Vascular plants of the Leeward Islands, Hawaii. Bernice P. Bishop Mus. Bull. 81.

Cleghorn, P. L. 1988. The settlement and abandonment of two Hawaiian outposts: Nihoa and Necker Islands. Bishop Mus. Occas. Pap. 28:35-49.

Colinvaux, P. A., P. E. De Oliveira, and J. E. Moreno. 1998. Amazon pollen manual and atlas. Harwood (Gordon and Breach), Amsterdam.

Dye, T. 1994. Apparent ages of marine shells: Implications for archaeological dating in Hawai'i. Radiocarbon 36:51-57.

Elschner, C. 1915. The Leeward Islands of the Hawaiian group. Reprinted from the Sunday Advertiser. The Advertiser Publ. Co., Honolulu.

Ely, C. A., and R. B. Clapp. 1973. The natural history of Laysan Island, Northwestern Hawaiian Islands. Atoll Res. Bull. 171. 
Fairbanks, R. G. 1989. A 17,000-year glacioeustatic sea level record: Influence of glacial melting rates on the Younger Dryas event and deep-ocean circulation. Nature (Lond.) 342:637-642.

Flenley, J. R., A. S. M. King, J. T. Teller, M. E. Prentice, J. Jackson, and C. Chew. 1991. The Late Quaternary vegetational and climatic history of Easter Island. J. Quat. Sci. 6 (2): 85-115.

Fletcher, C. H., III, and A. T. Jones. 1996. Sea-level highstand recorded in Holocene shoreline deposits on Oahu, Hawaii. J. Sediment. Res. 66 (3): 632-641.

Grossman, E. E., and C. H. Fletcher III. 1998. Sea level higher than present 3500 years ago on the northern main Hawaiian Islands. Geology (Boulder) 26 (4): $363-$ 366.

Lamoureux, C. H. 1963. The flora and vegetation of Laysan Island. Atoll Res. Bull. 97:1-14.

Lemmermann, E. 1905. Die algenflora der Sandwich-Inseln: Ergebnisse einer Reise nach dem Pacific, Schauinsland 1896-97. Bot. Jahrb. 34:607-663.

Lenz, P. 1984. Report on the ecology of the Laysan lake. Typescript copy, no title page. Available from U.S. Fish and Wildlife Service, Honolulu, and International Archaeological Research Institute, Inc., Honolulu.

Lyons, A. B. 1890. In bird land: Part of the journal of a visit to Laysan Island. The Friend 48 (12): 90-91.

Maciolek, J. A. 1982. Lakes and lake-like waters of the Hawaiian archipelago. Occas. Pap. Bernice P. Bishop Mus. 25 (1): 1-14.

Morin, M., and S. A. Conant. 1998. Laysan Island ecosystem restoration plan. Department of Zoology, University of Hawai'i at Mānoa, Honolulu. Available at Hamilton Library, University of Hawai'i.

Newman, A. L. 1988. Mapping and monitoring vegetation change on Laysan Island. M.A. thesis, University of Hawaici at Mānoa, Honolulu.
Patrick, R., and C. W. Reimer. 1966. The diatoms of the United States. Vol. 1. Monogr. Acad. Nat. Sci. Phila. 13.

Rauzon, M. J. 2001. Isles of refuge: Wildlife and history of the Northwestern Hawaiian Islands. University of Hawai'i Press, Honolulu.

Rothschild, L. W. 1893-1900. The avifauna of Laysan and the neighboring islands with a complete history to date of the birds of the Hawaiian possessions. 2 vols. R. H. Porter, London.

Schauinsland, H. H. 1996 [1899]. Three months on a coral island (Laysan). Translated by M. D. F. Udvardy. Atoll Res. Bull. 432.

Sherman, C. 1999. Appendix A: Geochemical analysis. Pages 207-208 in J. S. Athens, J. V. Ward, H. D. Tuggle, and D. J. Welch, Environment, vegetation change, and early human settlement on the 'Ewa Plain: A cultural resource inventory of Naval Air Station, Barbers Point, O'ahu, Hawai'i, Part III: Paleoenvironmental Investigations, Report prepared for Belt Collins Hawai'i, Honolulu, under contract to the Department of the Navy, Commander, Pacific Division, Pearl Harbor. International Archaeological Research Institute, Inc., Honolulu.

Stuiver, M., and P. J. Reimer. 1993. Extended ${ }^{14} \mathrm{C}$ data base and revised CALIB $3.0{ }^{14} \mathrm{C}$ age calibration. Radiocarbon 35:215-230.

Wagner, W. L., D. R. Herbst, and S. H. Sohmer. 1990. Manual of the flowering plants of Hawai'i. 2 vols. Bishop Museum Special Publication 83. University of $\mathrm{Ha}-$ wai'i Press and Bishop Museum Press, Honolulu.

Warner, R. E. 1963. Recent history and ecology of the Laysan Duck. Condor 65 (1): $3-23$.

Ziegler, A. C. 2002. Hawaiian natural history, ecology, and evolution. University of Hawai'i Press, Honolulu. 
